\title{
Spanish Working End Of Law Degree In The European Higher Education Area
}

Patricia Domínguez Alonso, Ph.D., University of Castilla-La Mancha, Spain

\begin{abstract}
The working end of Law Degree is called to develop an important role when we consider that the European Higher Education Area is the student manager of his own learning and is considered essential that the student of law, among other skills, to acquire critical thinking skills, investigation techniques, personal development work and use of legal principles and fundamental values as a working tool in the interpretation of the legal system.

The development of the working end of Law Degree in order to allow the student to a specific topic in depth and learn to develop a basic legal research. The work will enable the assessment of skills associated with the title of Bachelor of Laws.

To highlight an element of the research is that development of it should be conducted in an orderly and systematic manner for which the teacher's work is essential from the outset.

In this sense, the student, with guidance from the teacher must identify a target as the first topic of study. Much of the importance of the work lies in the student's learning method and technique to use. At this point, given that the study is done in the legal field, the work must be developed in stages, which are discussed in the communication. One final aspect to take into account and that is also the subject of analysis is the defense of the research to be undertaken before a court of teachers.
\end{abstract}

The paper shall provide thoughts on what this job should be to grade, allowing students to deepen a specific topic and learn how to develop a basic legal research. It also examines the role to develop both the tutor and the student throughout the work until the presentation and defense of the court appointed by the Faculty concerned.

Keywords: European Higher Education Area: The Bologna Declaration and ECTS Experiences

\section{INTRODUCTION : THE FORECAST IN THE NEW SPANISH DEGREE OF COMPLETION OF A FINAL WORK FOR GRADE}

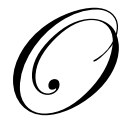

ne of the main novelties of the new spanish degree in the European Higher Education Area (EHEA) is that it provides for a final work for grade with the student may deepen a specific topic and learn to develop a basic research.

Among the main consequences of the implementation of the Bologna Declaration is the learning objective of teaching is what needs to be evaluated, this requires modifying traditional methods of examination to verify, among other things, that the student has learned, which has acquired the skills and knowledge, which is important to know do a research paper.

The Royal Decree 1393/2007, of October 29, which provides for the management of university officials, and to devise the system that will integrate in the EHEA Spanish university started in 1999 with the Bologna Declaration, Article 12 states guidelines for the design of graduate certificates and notes in paragraph 3 that these lessons will conclude with the development and advocacy work to grade. 
It should be borne in mind that the curriculum leading to the award of the degree will be developed by universities and verified in accordance with the provisions of Royal Decree.

However, the curriculum will have 240 credits, which contain all the theoretical and practical training that students should acquire: basic aspects of the branch of knowledge, compulsory or optional, seminars and external practices, guided, work order degree or other training activities.

The work order to Grade will have between 6 and 30 ECTS credits (European Credit Transfer System), must take place in the final phase of the curriculum and be oriented to the assessment of skills associated with the security in question.

\section{THE DIFFICULT REALIZATION OF THE GOALS OF LABOR LAW IN ORDER TO GRADE}

The degree to work in law's main objective is to enable a comprehensive assessment of key competencies that the student has achieved throughout his degree.

However, as highlighted GALINDO, F. (2009, pp. 2 et seq.) specifying what those skills and thus be required in order to work Degree in Law is the fundamental problem that has yet to be developed in anticipation of Spain Paragraph 9 of Article 12 of Royal Decree 1393/2007 which sets out explicitly:

"In the case of certificates to engage in regulated professional activities in Spain, the Government will establish the conditions which must be appropriate for the curriculum, which must also be adjusted, if necessary, to apply the European regulations. These curricula should, however, designed so as to obtain the skills necessary to practice this profession. To this end the University will justify the appropriateness of the curriculum to these conditions. "

Therefore, they are currently implementing the current guidelines themselves the title of the law in regard to its name, subject and content, as there is approval by the Government of conditions that place (transitional quarter -university degrees related to professional activities- of the RD 1393/2007-).

The conclusions of the XIII Conference of Deans of Faculties of Law of Spanish Universities, held at the Faculty of Law, University of Zaragoza 22 and May 23, 2007, noted that, at least in the Degree in Law should require the following competencies:

- $\quad$ Substantial knowledge of the rules and legal institutions and procedures of the system

- Understanding the basics of the contents of the master program has been proposed.

In this model, the teacher assumes his role as facilitator of knowledge, and each student is a manager of their own learning. This proposal seeks to provide:

- $\quad$ Skills for finding information

- Selection criteria of knowledge

- $\quad$ Skills assessment data

- $\quad$ Organizational and managerial skills of critical knowledge

- $\quad$ Techniques for individual study

- $\quad$ Critical thinking skills

- Discussion of collective knowledge

- $\quad$ Research Techniques

- Speech and techniques of argumentation

Similarly, to promote the independent study of students, enhance:

- $\quad$ Carrying out the tasks prescribed by the teacher

- Development of personal work 
- $\quad$ Making practices

- $\quad$ Teamwork

- $\quad$ Synthesis personal content on various

- $\quad$ Reading books and supporting material

- $\quad$ Attendance and participation in seminars

The ultimate goal is that the student has sufficient knowledge and skills that enable you to manage information and properly resolve specific legal problems that arise in day to day and that can tackle them with adequate decision-making capacity. It is, in short, to acquire skills that allow an autonomous learning and leadership and a spirit of enterprise. To this end, the program aims at training students who completed Grade develop their skills of organization, analysis and synthesis transmitting verbal and written language in the conclusions it reaches.

Moreover, the degree of law was also intended to be securitized (very important role in everyday lawyer who wants to be authentic and in areas as sensitive as those discussed in these studies). Thus, it is essential to convey to students the necessary sensitivity social, economic and environmental as well as ethical.

\section{THE INTRODUCTION TO RESEARCH. SOME IDEAS ON THE CONDUCT AND DEFENSE OF THE WORKING END OF A DEGREE IN LAW}

The degree to work is called to develop an important role when we consider that the EHEA is the student manager of his own learning and, as discussed above highlighted the findings of the XIII Conference of Deans of Law Faculties of Universities Spanish is considered essential to the student of law, among other skills, acquire critical thinking skills, research techniques, development of personal work and use of legal principles and fundamental values as a working tool in the interpretation of the law.

The development of labor law degree in order to allow the student to a specific topic in depth and learn to develop a basic legal research. The work will enable the assessment of skills associated with the degree of Bachelor of Laws.

Well, a highlight of the research is that development of that be done in a systematic and orderly manner and this teacher's work is essential from the outset.

In this sense, the student, with guidance from the teacher, you must define a goal as the first topic of study that is of interest (for their timeliness, novelty, importance, etc.). And are also sufficiently specific and precise. Be taken into account in the choice of subject the state of knowledge on the matter raised and the relevance of the study being proposed.

Much of the importance of the work lies in the student's learning method and technique to use.

At this point, given that the study is done in the legal field, the work must be developed in several phases:

a) As a first step will be to collect the literature, regulatory, and case documentation necessary for the proper conduct of the study. Access to primary and secondary sources require searches in libraries and on line.

b) In a second phase, materials are classified and analyzed and support the development of an initial outline of the work. This scheme is important for the success of the research process. The teacher should therefore teach the student to carry out this scheme and be developed in an appropriate manner.

c) In the third and final stage will make concrete proposals for resolving the problems and prepare the final text of the work.

The work will be done according to the methodology of legal science, but should not rule out the use of other vital scientific perspectives coming as sociological, political and economic.

You can also go to the methodology of comparative law. 
Formal aspects of the work-order of the exhibition, making the critical apparatus, quotations from literature, legislation and case law, formal presentation of the work ... - are also important and will enable students to acquire techniques that will be very useful in the development of their professional work.

The student must be emphasized the inadmissibility of plagiarism and the risks of going to it. In particular, this is especially problematic at present because of the ease of access to work via the Internet.

One final aspect to consider is the defense of the research to be undertaken before a court of teachers. In this regard it is normal that the Law School named three professors to the act of defense work, to be selected depending on the subject of work by specialty teachers.

Teachers board members must have a minimum working enough.

The student must be set in advance a time to defend his work, which ranges between 10 and 30 minutes.

These formal matters of defense work to a degree should be set in rules of the Faculty.

Ultimately, the nature discussed the work to a degree in law will affect key aspects of the new EHEA to affect the teaching methods of teachers, methods of study and learning of the learners, and methods of evaluation.

\section{AUTHOR INFORMATION}

Patricia Domínguez Alonso, PhD in Law by Autonoma University of Mexico State and Degree in Law by University of Castilla-La Mancha. Asistent Professor of Administrative Law at Public Law Department. Faculty of Social Sciences of Cuenca. University of Castilla-La Mancha (Spain). E-mail: Patricia.Dominguez@uclm.es.

Research Interest: Enviromental law, Water Law, administrative organization.

\section{REFERENCES}

1. Atienza, M. (2006) : The Law as argument. Conceptions of argument, Ariel, Barcelona.

2. Becker, H. S. (1986) : Writing for Social Scientists. How to Start and Finish Your Thesis, Book or Article, The University of Chicago Press, Chicago and London.

3. Bunge, M., (1985) : Scientific research, Ariel, Barcelona.

4. Corbett, P. (2006) : Methodology and Techniques of Social Research, McGrawHill, Madrid.

5. Courtis, C. (ed.) (2006): observe the law. Tests of legal methodology, Trotta, Madrid.

6. Galindo, F. (2009): "Learning the Law and the reform of Bologna", Diario La Ley No. 7127, pp. 2 ff.

7. Weston, A. (1994): Keys to the argument, Ariel, Barcelona. 